\title{
Combined effects of increased UV-B and temperature on the pigment-determined marine phytoplankton community of the St. Lawrence Estuary
}

\author{
M. Lionard ${ }^{1,2, *}$, S. Roy ${ }^{1}$, M. Tremblay-Létourneau ${ }^{1}$, G. A. Ferreyra ${ }^{1}$ \\ ${ }^{1}$ Institut des Sciences de la Mer de Rimouski (ISMER), Université du Québec à Rimouski, Rimouski, Québec G5L 3A1, Canada \\ ${ }^{2}$ Present address: Département de Biologie, Pavillon Alexandre-Vachon, Université Laval, Québec, Québec G1V 0A6, Canada
}

\begin{abstract}
The combined effects of increased UV-B and temperature on natural marine phytoplankton from the St. Lawrence Estuary (Canada) were examined in an $8 \mathrm{~d}$ mesocosm experiment carried out in Rimouski (Québec, Canada) in August 2008. We tested the hypothesis that increased temperature $\left(+3^{\circ} \mathrm{C}\right)$ will offset algal growth suppression by UV-B (78\% UV-B increase) using duplicate mesocosm experiments containing natural phytoplankton assemblages. The response of the entire phytoplankton community, in terms of HPLC pigment-based phytoplankton biomass, community composition (CHEMTAX), xanthophyll cycles photoprotection and quantum yield of photosystem II (the ratio of variable to maximum fluorescence: $F_{\mathrm{v}} / F_{\mathrm{m}}$ ), showed a significant influence of temperature (negative on small phytoplanktonic cells, $<5 \mu \mathrm{m}$, and positive on larger diatoms) but only after the peak of the diatom bloom, when nutrients became limited. Interactions between temperature and UV-B treatments were significant only for small cells during post-bloom; UV-B induced an increase in phytoplankton biomass at the normal temperature but had no effect at warmer temperatures. Enhancing UV-B delayed the bloom slightly under the normal temperature and spread it over a longer period of time, with no sign of major cellular damage. Our results do not support the tested hypothesis, and they suggest that temperature plays a greater role than UV-B radiation in structuring phytoplankton communities, possibly favouring diatoms rather than small cells in a warmer climate scenario. Other effects such as grazing or coastal eutrophication should be considered in future studies.
\end{abstract}

KEY WORDS: Mesocosm experiment - Ultraviolet-B radiation - Temperature $\cdot$ Phytoplankton · Global warming

\section{INTRODUCTION}

Since the middle of last century, gases of anthropogenic origin gradually destroyed the stratospheric ozone layer, causing an increase of UV-B radiation (280 to $315 \mathrm{~nm}$ ) at the Earth's surface (Kerr \& Mc Elroy 1993). Since the 1980s, the increase of UV-B has ranged from 6 to $14 \%$ at 10 sites of medium and high latitude (Kerr \& McElroy 1993, Madronich et al. 1995, WMO 2003, McKenzie et al. 2007). Although the ozone layer has improved in recent years (Dame- ris 2010), in most scenarios of global warming temperature will increase simultaneously with UV-B radiation (Stenger 2002). The Intergovernmental Panel on Climate Change (IPCC) report (IPCC 2007) provides predictions of future increases of UV-B, as well as temperature, associated with global climate change. Increases in ocean temperature have already been observed in recent decades, notably in polar regions, causing an acceleration of the ice mass losses in Greenland and the West Antarctic (Shepherd \& Wingham 2007, Velicogna 2009) and in the 
Arctic (Comiso et al. 2008). According to the latest IPCC report (IPCC 2007), the global ocean surface temperature will increase by around $3^{\circ} \mathrm{C}$ by the end of the present century because of global warming.

Both UV-B and temperature can affect algal physiology (e.g. Davison 1991, Vincent \& Roy 1993) and community composition (e.g. Xenopoulos et al. 2009); however, to date, few studies have considered how these factors interact. Previous research shows a negative relation between temperature and UV-B damaging effects; colder temperatures are generally associated with more negative effects of UV radiation (UV-A + UV-B: 280 to $400 \mathrm{~nm}$ ) in cyanobacteria (Roos \& Vincent 1998), alpine lake phytoplankton assemblages (Doyle et al. 2005), macroalgal rhodophytes (van de Poll et al. 2002), macroalgal chlorophytes (Rautenberger \& Bischof 2006) and macroalgal phaeophytes (Hoffman et al. 2003, Roleda 2009). This is consistent with the hypothesis that net UV inhibition reflects the balance between temperatureindependent photochemical damage and temperature-dependent biosynthetic repair (Roos \& Vincent 1998), which leads to the interaction of UV and global warming affecting phytoplankton abundance and taxonomic composition. However, the phytoplankton response varies with species, even within the same algal group (Halac et al. 2010), and other factors, such as nutrient limitation, can influence this response (Doyle et al. 2005, Beardall et al. 2009). In the context of global warming, several studies have examined the influence of temperature on planktonic ecosystems. Some of these have reported a decrease in phytoplankton biomass (notably diatoms) and a shift towards smaller cell sizes associated with warming (e.g. Lewandowska \& Sommer 2010), although others find beneficial effects of increased temperature on diatoms or dinoflagellates (Halac et al. 2010, Lassen et al. 2010).

Here we report the results of a mesocosm experiment in which temperature and UV-B were manipulated individually and in combination to evaluate their effects on phytoplankton biomass, community composition, photosynthetic performance and photoprotective capabilities (collectively referred to as phytoplankton response). Experiments using mesocosms allow the use of large volumes of seawater containing whole communities of plankton with significant control over the environmental conditions (Kemp et al. 2001, Petersen et al. 2003). Prior mesocosm experiments conducted in Rimouski (Mousseau et al. 2000, Chatila et al. 2001, Roy et al. 2006) examined the influence of UV-B radiation but the temperature, effect was not assessed. Here we tested the hypothesis that algal biomass, community composition and photosynthetic performance would benefit from simultaneous increases in UV-B and temperature and examined the role of photoprotective xanthophyll cycles (XC) in the phytoplankton response (Buma et al. 2000, Sobrino et al. 2005). In addition, we contrasted the phytoplankton response during all $8 \mathrm{~d}$ of the experiment with that during the nutrientlimited post-bloom period to see if nutrient-stressed cells show greater sensitivity towards UV-B stress, as observed in a number of previous studies (Bouchard et al. 2006, Longhi et al. 2006, Beardall et al. 2009, Korbee et al. 2010).

\section{MATERIALS AND METHODS}

\section{Mesocosms}

Large volumes of local natural seawater were distributed in a series of tanks (mesocosms) that were exposed to various temperature and UV-B treatments. These open-top mesocosms were comprised of 8 steel cylindrical tanks of $2 \mathrm{~m}^{3}(1.7 \mathrm{~m}$ deep by $1.5 \mathrm{~m}$ diameter) assembled together and placed outdoors on the grounds of the Institut des Sciences de la Mer's (ISMER) field station located in Rimouski on the St. Lawrence Estuary (Québec, Canada). Temperature was measured and regulated using external temperature exchangers and temperature controllers (Heaton N480D). UV-B radiation consisted of either natural solar UV conditions (NUVB) or enhanced UVB (HUVB) through the use of UV-B lamps (fluorescent tubes, Philips TL40W-12RS, peak emission at $313 \mathrm{~nm}$ ) following the protocol described by Díaz et al. (2006). Small wood boxes were installed above all mesocosms to house the UV-B lamps and to simulate the same shadow in the natural UV-B treatment. The seawater used to fill the tanks was first filtered through a $300 \mu \mathrm{m}$ Nitex mesh to remove large zooplankton. This was done to avoid bias among mesocosms and because the size (depth) of our mesocosms was too small to provide natural conditions of life for mesozooplankton and larger organisms (e.g. prevented normal vertical migrations). To ensure homogeneity among mesocosms, the seawater was mixed in an intermediary tank of $150 \mathrm{l}$ and then distributed simultaneously to the 8 mesocosms using 8 identical pipes originating from the intermediary tank. The regulating temperature system was activated once filling was complete. Seawater was mixed during the experiment using an aquarium air pump at a flow rate of $1000 \mathrm{l} \mathrm{h}^{-1}$. 
The experiment was conducted from 20 to $29 \mathrm{Au}-$ gust 2008. Seawater was sampled from the St. Lawrence Estuary using an intake pump at ISMER's field station $\left(48^{\circ} 30^{\prime} 52^{\prime \prime} \mathrm{N}, 68^{\circ} 28^{\prime} 06^{\prime \prime} \mathrm{W}\right)$; this pump collects water from a depth of $10 \mathrm{~m}$ at approximately $1 \mathrm{~km}$ from shore. Filling of the mesocosms was done on 20 August 2008 (Day 0, D0), and water samples were taken to check homogeneity among mesocosms. On the next day, the temperature was adjusted to 15 and $18^{\circ} \mathrm{C}$ respectively for the normal (NT) and high temperature (HT) treatments. No nutrients were added since local concentrations were relatively high (e.g. nitrate concentration was $11 \mu \mathrm{M}$ ) and judged to be sufficient for phytoplankton growth. The UV-B lamps were turned on in the morning of the first sampling day (22 August 2008, D1). There was a problem with 1 of the HUVB-NT mesocosms, possibly due to some leakage of freshwater into the mesocosm during a rainstorm. Following examination of the $\mathrm{pH}$, particulate organic carbon (POC), dissolved organic carbon (DOC), and cell counts of various organisms (not shown), this mesocosm was eliminated from further analysis.

\section{Treatments}

Four treatments were applied: normal UV-B and normal temperature conditions (NUVB-NT); normal UV-B and high temperature (NUVB-HT); high UV-B and normal temperature (HUVB-NT); and high UV-B and high temperature (HUVB-HT). Each treatment was applied in duplicate (2 mesocosms).

The normal temperature $\left(15^{\circ} \mathrm{C}\right)$ corresponds to in situ surface seawater temperature at the time of the experiment. The temperature was monitored every minute during the experiment to keep it as stable as possible. The difference of $3^{\circ} \mathrm{C}$ between HT and NT corresponds to the expected local increase in temperature that would be caused by global warming (IPCC 2007).

The HUVB treatment was applied using 4 UV-B lamps to increase the mean $( \pm \mathrm{SD})$ UV-B irradiance in the water column by $78 \pm 9 \%$ (using the formula from Talling 1971; see our Fig. 1). This increase in UV-B was determined on the basis of a $60 \%$ local ozone depletion scenario according to the model of Díaz et al. (2003), and it is in the range of increases applied in previous studies (e.g. Roy et al. 2006, Häder 2011). The UV-B lamps were turned on every day during $4 \mathrm{~h}$ around mid-day, from 10:00 to 14:00 h. A film of cellulose acetate (125 $\mu \mathrm{m}$ thick; Sabic polymer- shapes) was placed around each lamp to remove UVC (100 to $280 \mathrm{~nm}$ ). This film was changed every morning as it is easily damaged by UV radiation, which changes its transmittance properties with time (Steeneken et al. 1995). Daily sampling of the mesocosms took place at 10:00 h, immediately before turning on the UV-B lamps, and at 14:00 h, immediately after turning off the UV-B lamps.

\section{Physical, chemical and biological measurements}

$$
\text { Irradiance }
$$

Ground and profiling radiometers (models GUV541 and PUV-542T respectively; Biospherical Instruments) were used to monitor the irradiance during the experiment, both outside and within the water column of the mesocosms (vertical profiles). The GUV monitored incident photosynthetically available radiation (PAR; 400 to $700 \mathrm{~nm}$ ), UV-A (at 320, 340 and $380 \mathrm{~nm}$ ) and UV-B (at 305 and $313 \mathrm{~nm}$ ) irradiance every second, and data were averaged over 15 min. PUV vertical profiles (same wavelengths as the GUV instrument) were done 3 times a day (at 10:00, 15:00 and 20:00 h) in each mesocosm. After measurement, the PUV was rinsed first with distilled water and then with seawater from the next mesocosm to be sampled in order to avoid contamination between mesocosms.

\section{Nutrients}

For nutrients, 3 replicate water samples $(60 \mathrm{ml})$ were taken daily at 08:00 $\mathrm{h}$ from each mesocosm. The sampled water was filtered through a $25 \mathrm{~mm}$ nitrocellulose filter $(0.22 \mu \mathrm{m}$ pore size) and stored at $-20^{\circ} \mathrm{C}$ until analysis. Phosphate, nitrate and silicate concentrations were measured using a Bran Luebbe AA3 analyzer, following the analytical procedures of Murphy \& Riley (1962), Armstrong et al. (1967), and Grasshoff et al. (1983), respectively. The analyses were completed within $30 \mathrm{~d}$ after the end of the experiment.

\section{Phytoplankton analyses: HPLC-determined pigments and fluorescence}

Sampling took place in the morning before turning on the UV-B lamps and in the afternoon immediately after turning off the UV-B lamps. A seawater volume 
of 11 was sampled from each mesocosm and immediately processed. This water was used for in vivo fluorescence measurements, and filtrations were done to determine pigments.

In vivo fluorescence was measured using an Aquafluor Turner Designs fluorometer, model 8000-007. The dark-adapted minimal fluorescence $\left(F_{0}\right)$ was measured after leaving the samples in a dark cooler for $30 \mathrm{~min}$. Maximal fluorescence $\left(F_{\mathrm{m}}\right)$ was measured following $F_{0}$ and after the addition of 3-(3,4-dichlorophenyl)-1,1-dimethyl urea (DCMU; Malkin \& Kok 1966) (final concentration: $3 \mathrm{mM}$ in ethanol). DCMU is an inhibitor of photosynthesis that causes closure of the photosynthetic reaction centers of photosystem II (PSII). The maximum quantum yield of PSII, $F_{\mathrm{v}} / F_{\mathrm{m}}=\left(F_{\mathrm{m}}-F_{0}\right) / F_{\mathrm{m}}$, was calculated according to Butler (1978), where variable fluorescence, $F_{v}$, is defined as $\left(F_{\mathrm{m}}-F_{0}\right)$

Total and size-fractionated phytoplankton pigments were analyzed by HPLC using the method of Zapata et al. (2000). For total phytoplankton pigment analyses, a volume of 400 to $700 \mathrm{ml}$ water was filtered on $25 \mathrm{~mm}$ diameter Whatman GF/F glass fiber filters. For size-fractionated pigments, a volume of 400 to $600 \mathrm{ml}$ water was first passed through a $5 \mu \mathrm{m}$ Nuclepore filter, and the $<5 \mu \mathrm{m}$ filtrate was then filtered on a $25 \mathrm{~mm}$ diameter Whatman GF/F glass fiber filter. A $5 \mu \mathrm{m}$ threshold was chosen to avoid filter clogging, which often occurs rapidly with smaller pore-sized filters in coastal waters. Moreover, results from a flow cytometry study conducted in parallel showed a different behavior for cells $<3 \mu \mathrm{m}$ compared with those $\geq 5.7 \mu \mathrm{m}$ in size (Thyssen et al. 2011). GF/F filters were wrapped in aluminum foil, immediately frozen in liquid nitrogen and then stored at $-80^{\circ} \mathrm{C}$ until analysis. Pigments were extracted from the filter in ice-cold 95\% methanol using a sonicator (Ultrasonic Processor XL 2010), and the internal standard apo-carotene (trans$\beta$-Apo-8'-carotenal, Sigma-Aldrich) was added to each sample to correct for possible extraction and injection bias. Pigments were separated on a reversed phase C8 Waters Symmetry column (150 × $4.6 \mathrm{~mm}, 3.5 \mu \mathrm{m}$ ) and detected using a Thermo Separation FL 3000 fluorescence detector in series with a photodiode array detector (Thermo Separation UV6000). They were identified using retention time, visible spectrum and comparison with standards from DHI Water and Environment. The HPLC limit of detection (LOD) and limit of quantification (LOQ) for chlorophyll a (chl a) were 0.005 and $0.016 \mu \mathrm{g} \mathrm{l}^{-1}$ respectively, using the approach described in Hooker (2005).

\section{Data analyses}

\author{
Algal groups
}

The contribution of major algal groups to total chl a was estimated using a new version of the CHEMTAX software developed by Mackey et al. (1996), courtesy of Dr. Simon Wright (CHEMTAX 195). The initial matrix of accessory pigments to chl a ratios (Table 1) included all algal groups previously observed in the St. Lawrence Estuary in summer (Roy et al. 1996) and used the pigment-based types of phytoplankton from Jeffrey \& Wright (2006).

\section{Photoprotective pigments}

Pigment-based photoprotection was assessed by examining the response of the XC pigments (Olaizola et al. 1994, Demmig-Adams \& Adams 1996). Based on the pigments detected, both the diadinoxanthin- and violaxanthin-based XC were present. Two aspects of photoprotection were examined: longterm photoacclimation through adjustment of the $\mathrm{XC}$ pigment pool, and short-term photoregulation through adjustment of the XC activity (van de Poll \& Buma 2009). The pool of photoprotective pigments in each of these was assessed through the ratios ( $\mathrm{Dd}+$ $\mathrm{Dt}) / \mathrm{chl} a$ and (Viola + Zea)/chl a where Dd is diadinoxanthin, Dt is diatoxanthin, Viola is violaxanthin, and Zea is zeaxanthin. Short-term photoregulation was examined using the de-epoxidation state (DES), an indication of photoprotection for phytoplankton cells (Brunet et al. 1993, Moline 1998, Ruban et al. 2004). DES for the diadinoxanthin-based XC was expressed as $\mathrm{DES}_{\mathrm{Dt}}=\mathrm{Dt} /(\mathrm{Dt}+\mathrm{Dd})$, and $\mathrm{DES}_{\mathrm{Zea}}=\mathrm{Zea} /$ $($ Zea + Viola) for the violaxanthin-based XC.

\section{Statistical tests}

Homogeneity of variances and normality were tested with Levene and Kolmogorov-Smirnov tests, respectively, using Statistica v. 10. When necessary, $\log _{10}$ or 4 th root transformations were applied to normalize the data. When all $8 \mathrm{~d}$ were considered, a $\log _{10}$ transformation was applied on chl $a<5 \mu \mathrm{m}$, (Dd $+\mathrm{Dt}) / \mathrm{chl} a$, and $\mathrm{DES}_{\mathrm{Dt}}$, while a 4 th root transformation was applied on total chl $a$. When post-bloom data were processed, a $\log _{10}$ transformation was applied on $\mathrm{DES}_{\mathrm{Dt}}$ and (Zea + Viola)/chl a while a 4th root transformation was applied on $(\mathrm{Dd}+\mathrm{Dt}) / \mathrm{chl} a$ data. Repeated measures multivariate analyses of 


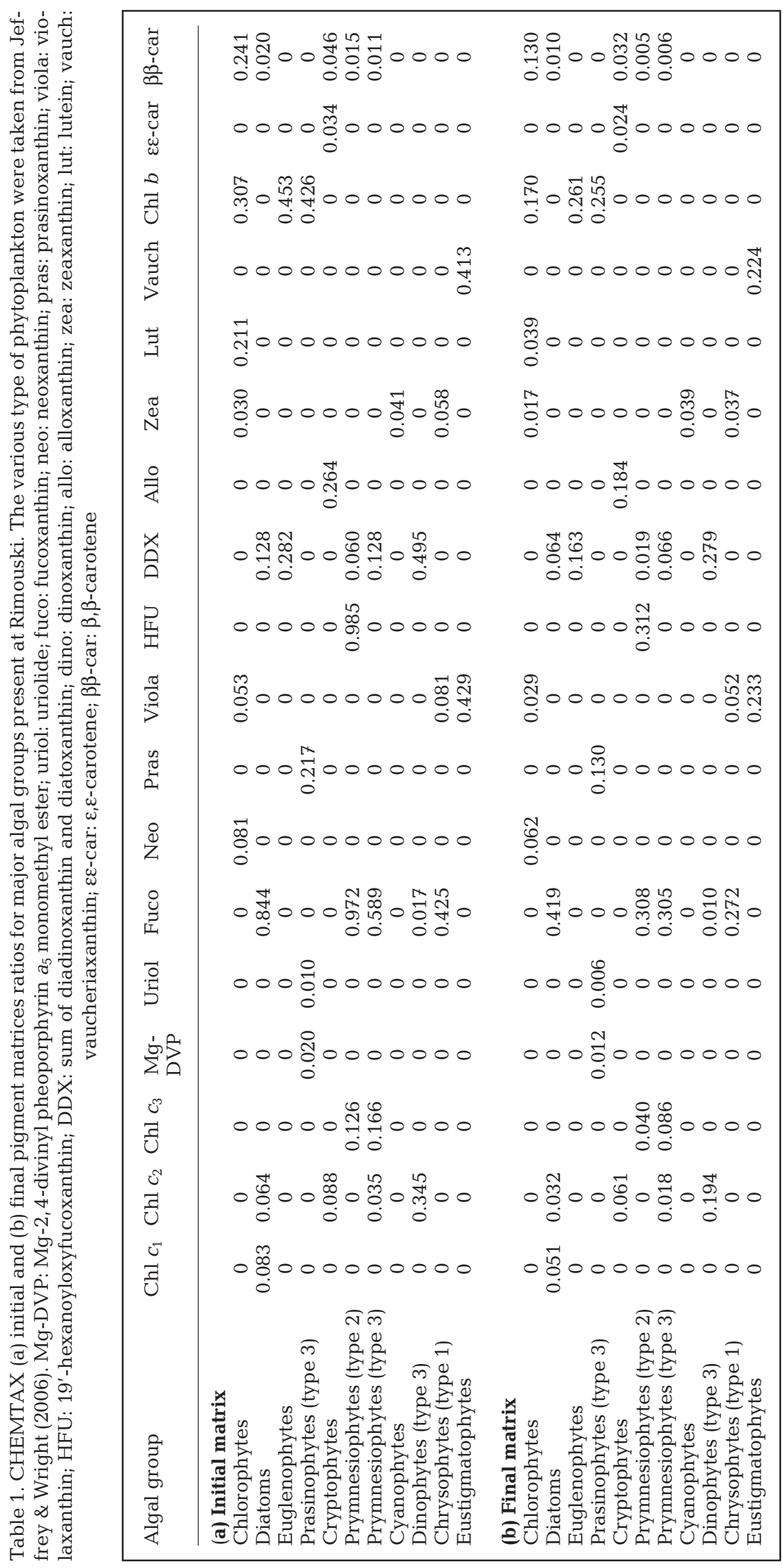

variance tests (RM-MANOVAs) were used to examine the overall effect of the UV-B and temperature treatments and their interaction over all the major algal groups determined from CHEMTAX. Repeated measures analyses of variance (RM-ANOVAs) were applied on univariate data (such as total chl $a_{\text {, }}$ chl $a<5 \mu \mathrm{m}$ ) and on individual algal groups when a significant overall effect was observed in the MANOVAs. Tukey's post-hoc statistical analyses were used when results were significant. Student's t-tests were used to compare nutrients concentration and $F_{\mathrm{v}} / F_{\mathrm{m}}$ ratio from the morning and from the afternoon (before and after UV-B exposure). Results from the first day (water filling; D0) were not considered in the statistical analyses as this was considered to be the initial stabilization period.

\section{RESULTS}

\section{Irradiance, temperature and nutrients}

The average mid-day incident irradiance at the mesocosms' surface ranged from 0.008 to $0.190 \mu \mathrm{E}$ $\mathrm{cm}^{-2} \mathrm{~s}^{-1}$ for PAR and from 1.006 to $14.799 \mu \mathrm{W} \mathrm{cm} \mathrm{nm}^{-1}$ for solar UV-B (at 313 nm, Fig. 1a). The mean irradiance in the water column at noon was estimated following MacIntyre \& Cullen (1996). For PAR, the whole depth of the mesocosms was considered because the depth of the euphotic zone $\left(Z_{\text {eu }}, 1 \%\right.$ of incident) was deeper than the depth of the water column. Average PAR ranged from $0.004 \mu \mathrm{E} \mathrm{cm} \mathrm{cm}^{-2} \mathrm{~s}^{-1}$ on D4 to $0.119 \mu \mathrm{E}$ $\mathrm{cm}^{-2} \mathrm{~s}^{-1}$ on D5 (Fig. 1c). The depth of the photoactive zone $\left(Z_{\mathrm{ph}}, 10 \%\right.$ of incident, the depth over which UV-B has significant effects; Neale et al. 2003) was $\sim 30 \mathrm{~cm}$. Noon averages of weighted UV-B irradiances in the water column were computed over this depth and only the $313 \mathrm{~nm}$ averages are shown in Fig. 1d, corre- 

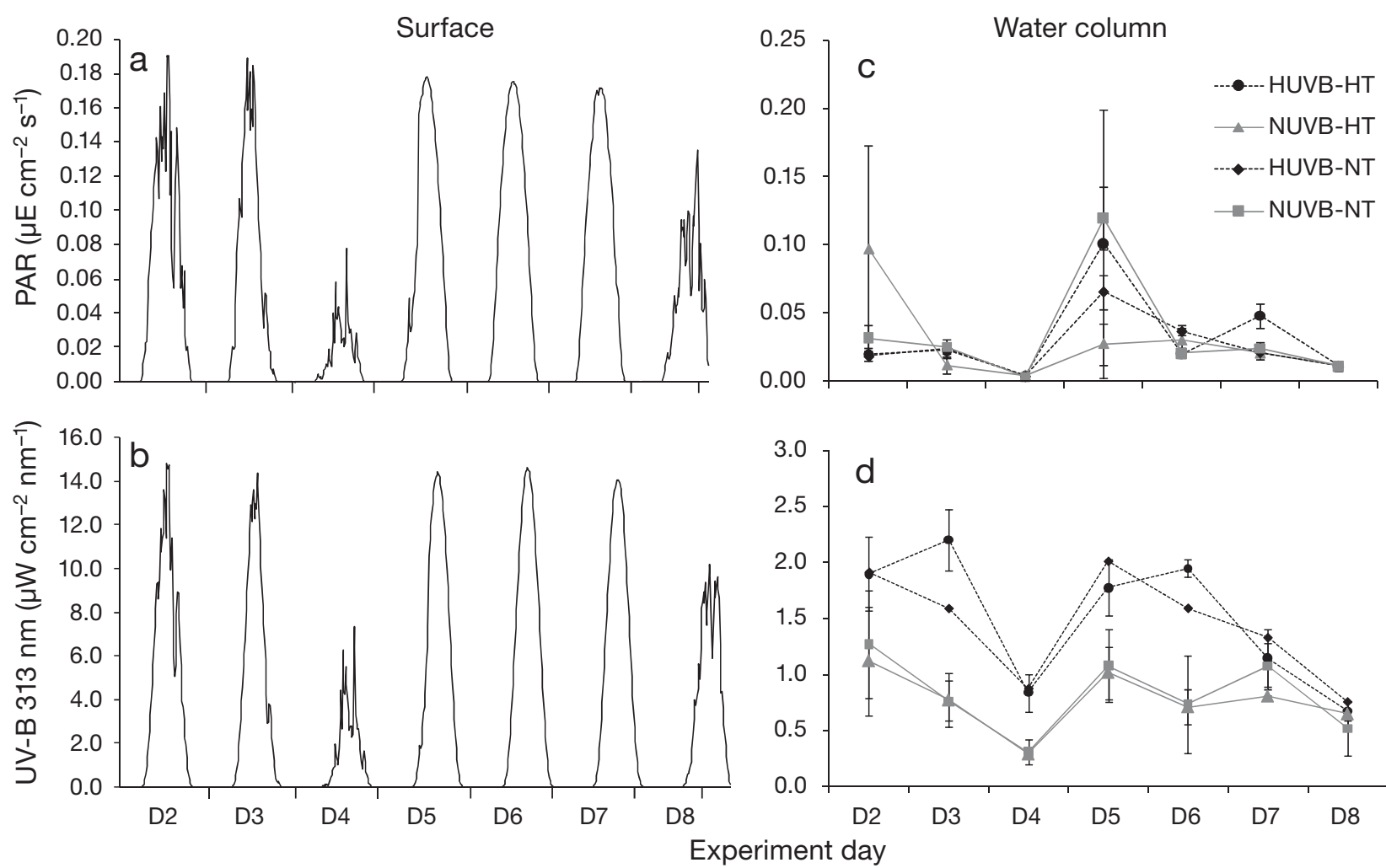

Fig. 1. (a) Mean photosynthetically active radiation (PAR) irradiance $\left(\mu \mathrm{E} \mathrm{cm}^{-2} \mathrm{~s}^{-1}\right)$ and (b) mean ( \pm SD) UV-B irradiance at $313 \mathrm{~nm}\left(\mu \mathrm{W} \mathrm{cm} \mathrm{cm}^{-2} \mathrm{~nm}^{-1}\right)$ at the surface of mesocosms measured by the ground radiometer (GUV) from Day 2 (D2) to Day 8 (D8). (c) Mean PAR irradiance $\left(\mu \mathrm{E} \mathrm{cm}^{-2} \mathrm{~s}^{-1}\right)$ and (d) mean ( $\left.\pm \mathrm{SD}\right) \mathrm{UV}$-B irradiance at $313 \mathrm{~nm}\left(\mu \mathrm{W} \mathrm{cm}^{-2} \mathrm{~nm}^{-1}\right)$ in the water column for each mesocosm treatment each day from D2 to D8. Replicates for the HUVB-NT treatment were not considered due to technical problems. Mesocosm treatments - HUVB-HT: high UV-B, high temperature treatment; HUVB-NT: high UV-B, normal temperature; NUVB-HT: normal UV-B, high temperature; NUVB-NT: normal UV-B, normal temperature

sponding to the emission peak of the UV-B lamps. Weighted UV-B values were estimated using Neale \& Kieber's (2000) biological weighting function for photosynthetic inhibition of diatoms and dinoflagellates, as these groups, particularly diatoms, were present in the mesocosms. The unweighted irradiances for HUVB and NUVB treatments ranged from 0.67 to $2.20 \mu \mathrm{W} \mathrm{cm}{ }^{-2} \mathrm{~nm}^{-1}$ and from 0.29 to $1.27 \mu \mathrm{W}$ $\mathrm{cm}^{-2} \mathrm{~nm}^{-1}$ respectively (Fig. 1b). Weighted UV-B values just below the surface at noon ranged between 30 and $140 \mu \mathrm{W} \mathrm{cm}{ }^{-2}$ for the NUVB treatments and between 74 and $291 \mu \mathrm{W} \mathrm{\textrm {cm } ^ { - 2 }}$ for the HUVB treatments. The relative increase between HUVB and NUVB treatments averaged 2.3, similar to previous mesocosm experiments reported for the St. Lawrence (Mostajir et al. 1999).

Temperature in the mesocosms was steady from D2 onwards and ranged from 15.05 to $15.49^{\circ} \mathrm{C}$ for the NT treatments and from 17.44 to $18.53^{\circ} \mathrm{C}$ for the HT treatments. The difference between NT and HT treatments was thus kept at $3 \pm 0.3^{\circ} \mathrm{C}$.
Table 2. Mean $( \pm \mathrm{SD})$ nutrient concentration $(\mu \mathrm{M})$ in mesocosms at the beginning (Day [D] 0), middle (D4) and end (D7) of the experiment. Nitrate and phosphate concentrations are based on all 7 mesocosms (4 treatment groups [see 'Materials and methods: Treatments'], 3 of them in duplicate). Silicate concentration is based on 6 mesocosms (excluding HUVB-NT [high UV-B, normal temperature]), with the results for the HUVB-NT treatment (only 1 mesocosm) presented separately

\begin{tabular}{|ccccc|}
\hline & $\mathrm{NO}_{3}{ }^{-}$ & $\mathrm{PO}_{4}{ }^{3-}$ & $\mathrm{Si}(\mathrm{OH})_{4}$ & $\mathrm{Si}(\mathrm{OH})_{4}$ \\
& & & & $\begin{array}{c}\text { excl. HUVB-NT) } \\
\text { (HUVB-NT } \\
\text { only) }\end{array}$ \\
\hline D0 & $11.12(0)$ & $0.89(0)$ & $15.42(0)$ & 15.42 \\
D4 & $0.71(0.66)$ & $0.09(0.02)$ & $1.90(0.99)$ & 7.09 \\
D7 & $0.00(0.36)$ & $0.07(0.09)$ & $0.00(0.02)$ & 0.00 \\
\hline
\end{tabular}

Nutrient concentrations are presented in Table 2; they decreased during the experiment from D0 to D7 and were depleted after the peak of the bloom (see next section for bloom periods). There were no signif- 
icant differences among treatments for nitrate and phosphate concentrations, but silicate concentrations were significantly larger in the HUVB-NT treatment (Student's $t$-tests, $\mathrm{p}<0.05)$, where the timing of the bloom occurred 2 d later than in the other mesocosms.
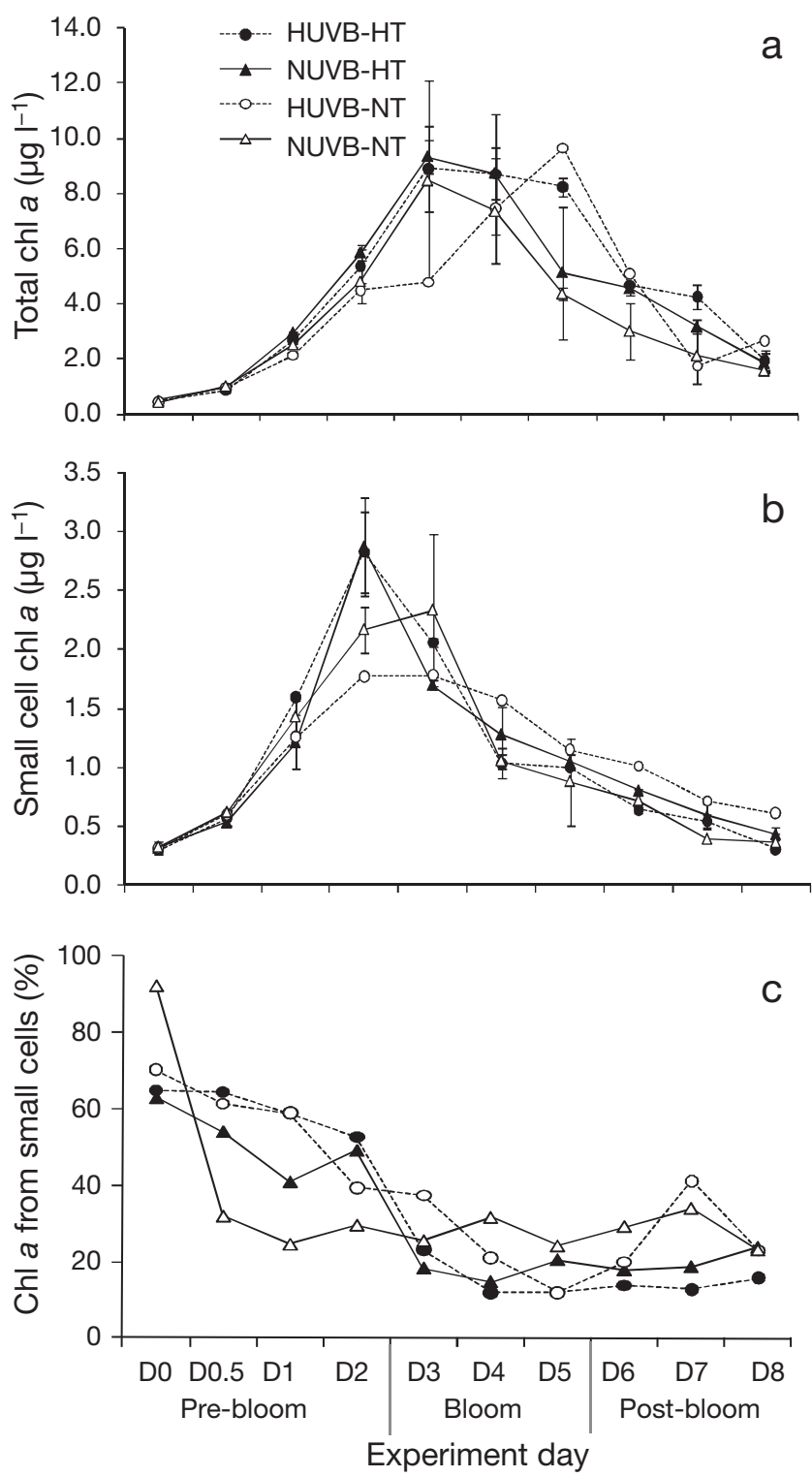

Fig. 2. Temporal patterns for (a) mean $( \pm \mathrm{SD})$ total chl a concentration measured with GFF filters, (b) mean $( \pm \mathrm{SD})$ chl a concentrations of the small phytoplankton fraction $(<5 \mu \mathrm{m})$ and (c) the percentage of chl a contributed by small phytoplankton to the total chl $a$, all in $\mu \mathrm{g}^{-1}$ measured daily over $8 \mathrm{~d}$ (Day 0, D0, to Day 8, D8) after the daily UV-B exposure. (-) HUVB-HT: high UV-B, high temperature treatment; (O) HUVB-NT: high UV-B, normal temperature; $(\boldsymbol{\Delta})$ NUVB-HT: normal UV-B, high temperature; $(\Delta)$ NUVB-NT: normal UV-B, normal temperature

\section{Phytoplankton biomass and composition}

Since no significant differences were observed in phytoplankton biomass (in terms of chl a) or composition (CHEMTAX-derived) between samples taken before and after the daily UV-B lamp exposure (see 'Daily changes before and after UV-B exposure', below), we present data only from the afternoon sampling (post-exposure). A bloom developed in the mesocosms within 3 to $5 \mathrm{~d}$, as seen in the chl a concentration (Fig. 2a). Three periods can be distinguished: D1 to D2 represent the pre-bloom period, D3 to D5 the bloom period, and D6 to D8 the postbloom period. Treatments HUVB-HT, NUVB-HT, NUVB-NT reached their maximum chl a concentration on D3 with 8.90, 9.33 and $8.49 \mu \mathrm{g} \mathrm{l}^{-1}$ respectively. On the other hand, the HUVB-NT mesocosm reached its maximum on D5 with a chl a concentration of $9.60 \mu \mathrm{g} \mathrm{l}^{-1}$. This delayed peak in algal biomass likely explains the higher silicate concentration remaining on D4 to D7 for this treatment, compared with the others. Phytoplankton biomass showed a strong decrease on D5 and following days for the NUVB-NT and NUVB-HT treatments, while the bloom remained for 2 more days in the HUVB-HT treatment and both HUVB treatments declined after D5. Small cells $(<5 \mu \mathrm{m})$ made up over $60 \%$ of the total chl $a$ at the start of the experiment, but this proportion decreased to less than $40 \%$ as the bloom developed (Fig. 2c). The chl a concentration of the small size fraction reached its maximum on D2 for HT treatments and D3 for NT treatments (Fig. 2b). When all $8 \mathrm{~d}$ were considered for total or small cell chl a concentration, there were no significant effects of the temperature or UV-B treatments (or their interaction, Table 3a). However, both factors and their interaction were significant when the post-bloom period was examined, with inverse effects of temperature on large and small cells but similar effects of UV-B (Table 3b). Contrary to expectations, enhanced UV-B had a positive effect on algal biomass (large and small cells) and increasing the temperature favored large rather than small cells during the post-bloom.

The phytoplankton community was examined using CHEMTAX results, which showed a succession of algal groups during the experiment (Fig. 3). On the first days, prasinophytes, chrysophytes and chlorophytes dominated the community with an average of 25, 21 and $19 \%$, respectively, of the phytoplankton biomass. Diatoms appeared on D1. Their importance increased with time and reached a maximum on D4, when they represented on average $85 \%$ of the total chl a biomass. During post-bloom, the relative proportion 


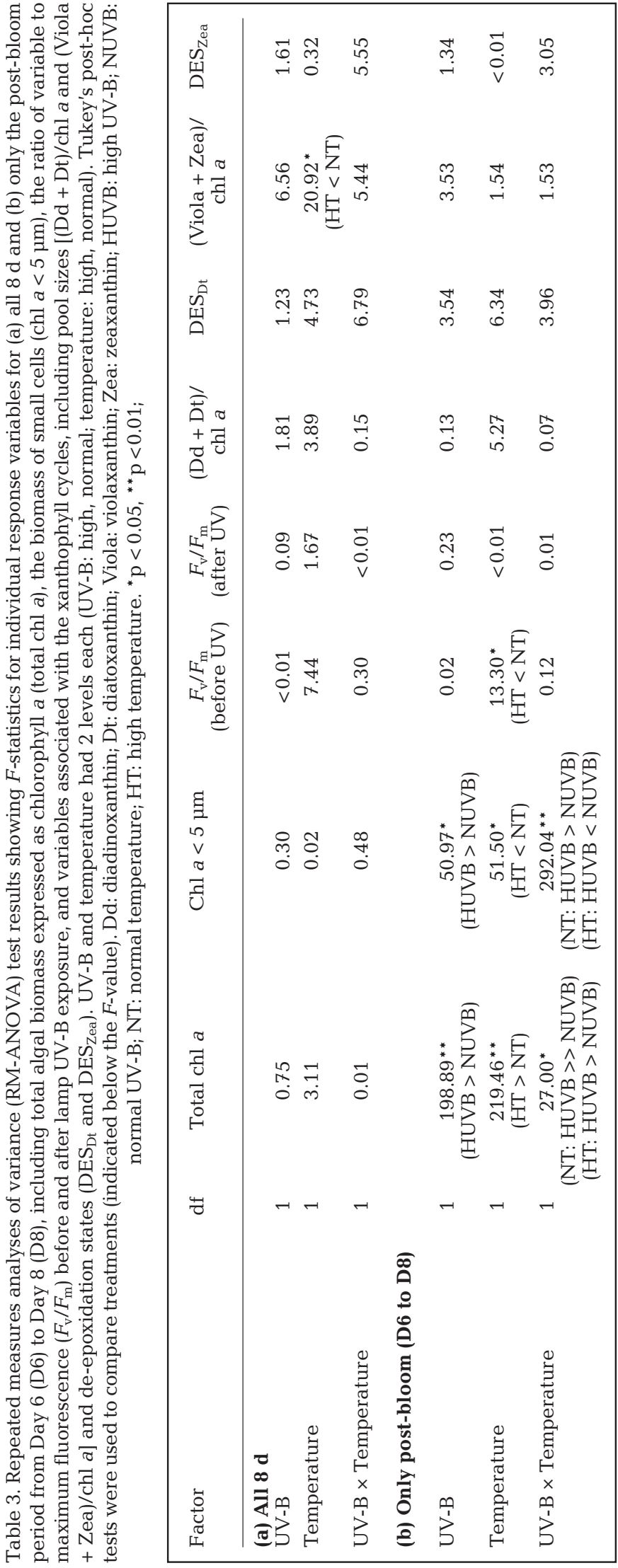

of diatoms decreased slightly compared to the bloom period, while that of dinoflagellates increased. There was no extensive microscopic identification done during this study, but rapid observations confirmed the presence of diatoms (Chaetoceros spp. and Thalassiosira spp.) and green algae (Chlamydomonas sp.).

For small-cell size-fractionated samples, CHEMTAX showed an initial dominance of euglenophytes and chrysophytes, followed by prasinophytes over the first $3 \mathrm{~d}$ (Fig. 4). Then, small diatoms dominated from D4 to D7, particularly in the high temperature treatment, with a maximum of up to $40 \%$ in HUVBHT on D6. During post-bloom, chrysophytes dominated in the NUVB-NT treatment on D6 and D7 $(27 \%)$, while prymnesiophytes type 3 replaced the diatoms as the dominant group on the last day (up to $33 \%$ in NUVB-HT).

RM-MANOVA was used to examine differences in all the response variables (e.g. CHEMTAX-derived algal groups) taken simultaneously. Results for the whole period (8 d) and for all cells (GFF-filtered) showed a significant influence of temperature and algal groups but not UV-B nor its interaction with temperature (Table 4a). Increasing the temperature increased the biomass of the algal community, specifically diatoms. The response differed significantly among the algal groups, notably for diatoms (Table 4a). The temperature response was similar during the post-bloom period, again associated with diatoms (Table 4b).

In contrast with the response observed for all cells, small cells showed a significant decrease with temperature over the whole duration of the experiment, with no significant influence from UV-B or its interaction with temperature (Table 4a). Again, the response differed according to the algal groups; prasinophytes and diatoms were different than other groups. There was also a significant interaction between small-size algal groups and temperature, with a significant decrease in euglenophytes (but not other groups) associated with higher temperature (Table 4a). The temperature effect disappeared during post-bloom and was replaced by a UV-B effect (small cells increasing under enhanced UV-B), along with a significant interaction with temperature (Table 4b). At higher temperatures, increasing UV-B had either no effect (RMMANOVA on community results, Table $4 \mathrm{~b}$ ) or a negative effect on small cells (RM-ANOVA on sizefractionated chl $a$, Table $3 b$ ) while at normal temperatures, the small-cell community was favored under the HUVB treatment (Tables 3b \& 4b, Fig. 2b).

When the cumulative biomass at the end of the $8 \mathrm{~d}$ of the experiment was compared for the major 


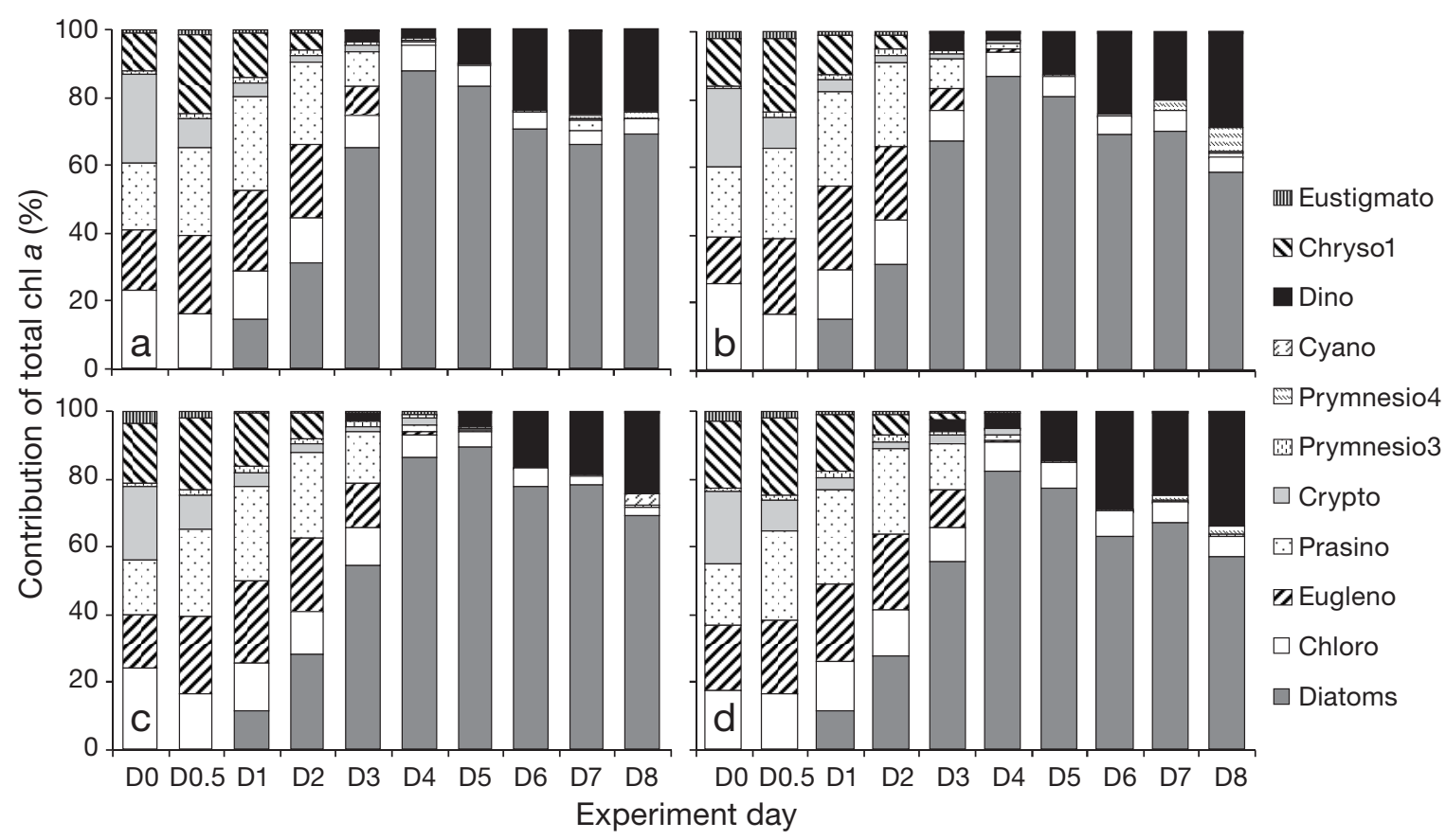

Fig. 3. Phytoplankton community groups, expressed in percentage of the total chl a concentration, obtained from CHEMTAX analysis after UV-B exposure in all treatments and measured daily over the $8 \mathrm{~d}$ (Day 0, D0, to Day 8, D8) experiment: (a) high UV-B, high temperature, (b) normal UV-B, high temperature, (c) high UV-B, normal temperature, (d) normal UV-B, normal temperature. Eustigmato: eustigmatophytes; chryso1: chrysophytes (type 1); dino: dinoflagellates; cyano: cyanobacteria; prymnesio3 and prymnesio4: prymnesiophytes (types 3 and 4); crypto: cryptophytes; prasino: prasinophytes; eugleno: euglenophytes; chloro: chlorophytes

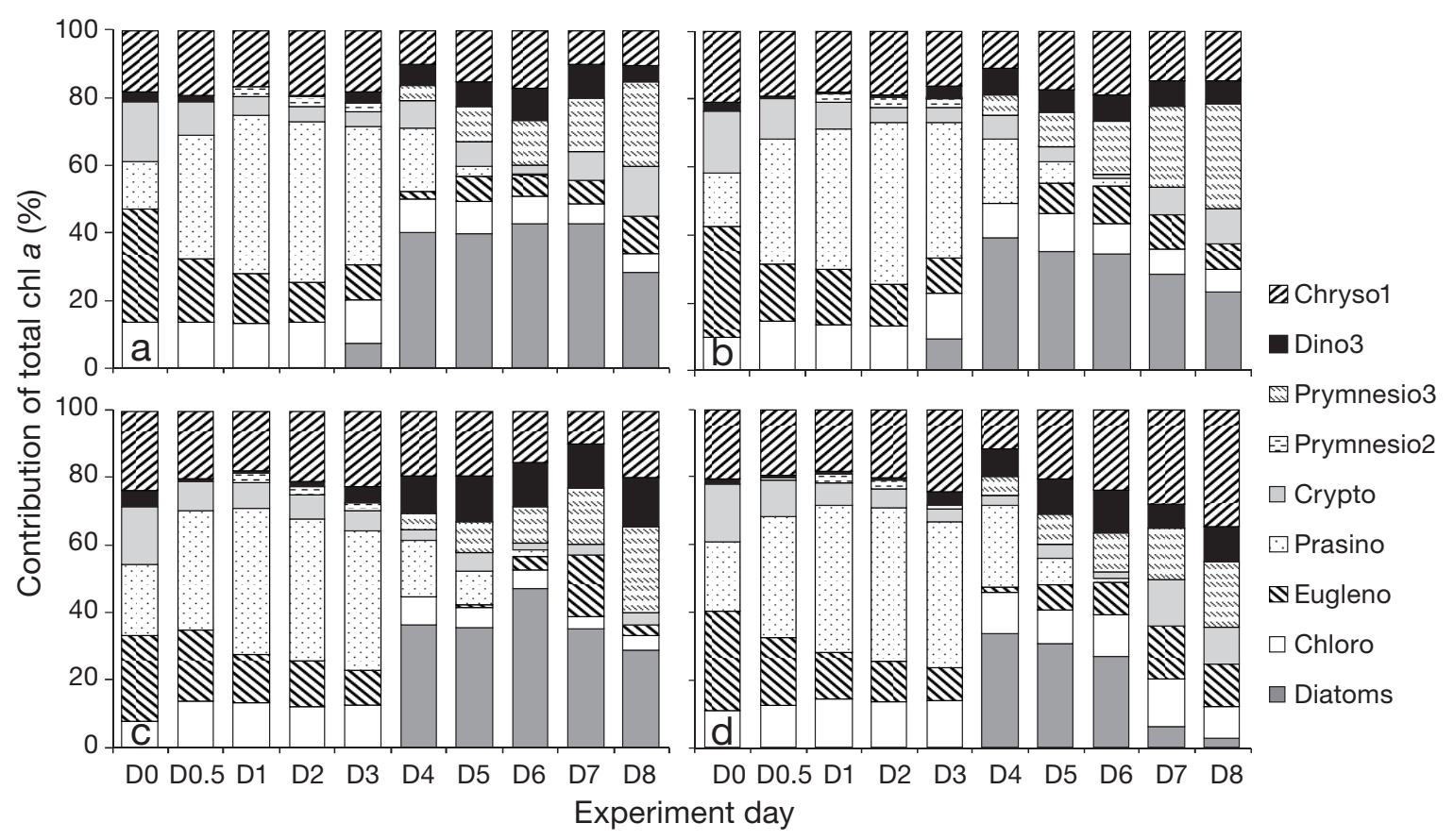

Fig. 4. Phytoplankton community groups for the small $(<5 \mu \mathrm{m})$ phytoplankton fraction, expressed in percentage of the total chl $a$ concentration, obtained from CHEMTAX analysis after UV-B exposure in all treatments measured daily over the $8 \mathrm{~d}$ (Day 0, D0, to Day 8, D8) experiment: (a) high UV-B, high temperature, (b) normal UV-B, high temperature, (c) high UV-B, normal temperature, (d) normal UV-B, normal temperature. dino3: dinoflagellates (type 3); prymnesio2: prymnesiophytes (type 2). For other group definitions see Fig. 3 
Table 4. Repeated measures multivariate analyses of variance (RM-MANOVA) test results showing $F$-statistics for (a) all $8 \mathrm{~d}$ and (b) only the post-bloom period from Day 6 (D6) to Day 8 (D8) on the biomass of the various algal groups (as chl $a$, from the CHEMTAX results) for cells of all sizes and for cells $<5 \mu \mathrm{m}$. UV-B and temperature factors had 2 levels each (high, normal). Algae had 8 levels for all cells and 4 levels for small cells because the less common groups were combined. Tukey's post-hoc tests were used to compare treatments with significant results (indicated below the $F$-value). HT: high temperature; NT: normal temperature; HUVB: high UV-B; NUVB: normal UV-B; prasino: prasinophytes eugleno: euglenophytes. ${ }^{*} \mathrm{p}<0.05 ;{ }^{* *} \mathrm{p}<0.01$

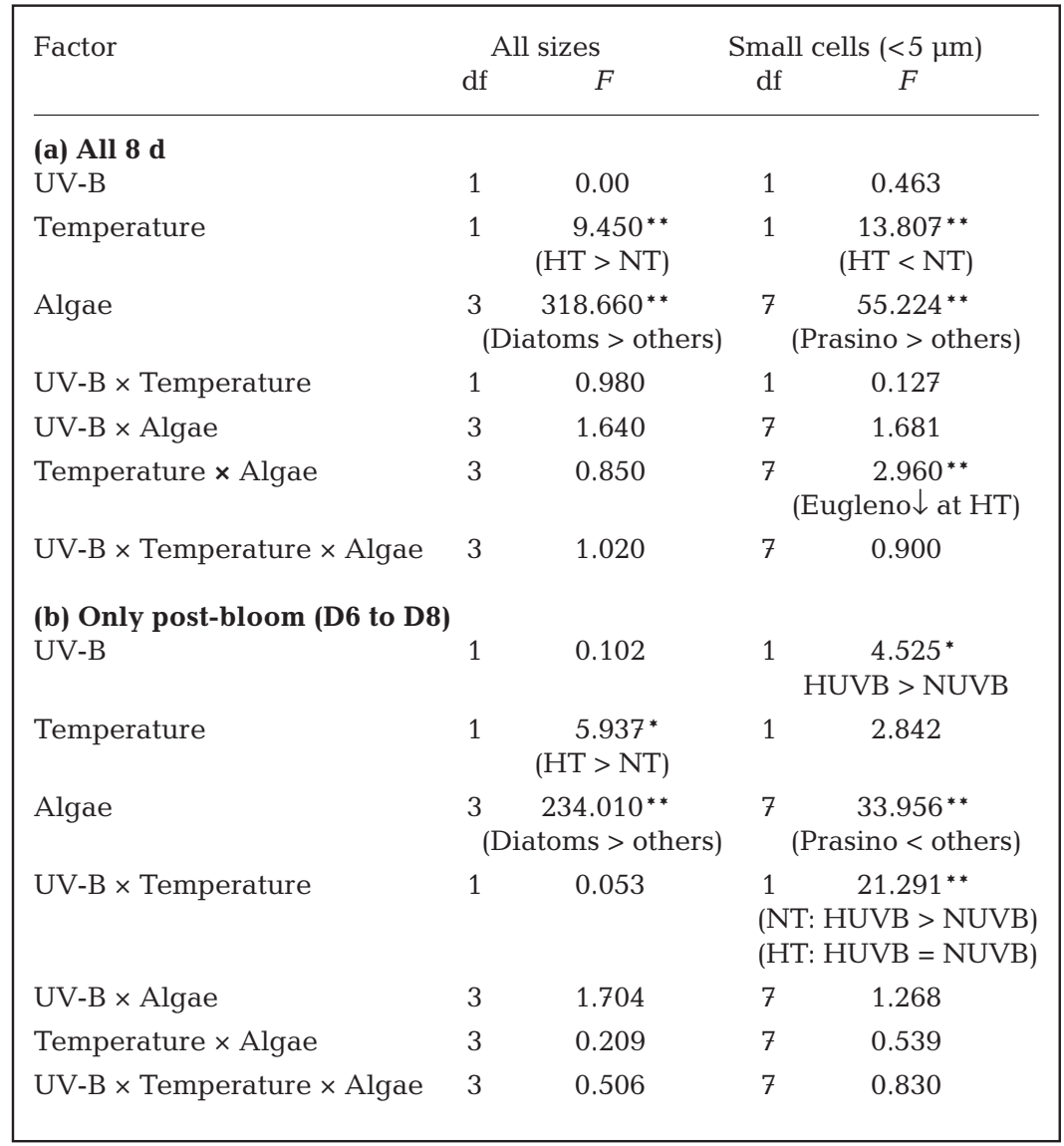

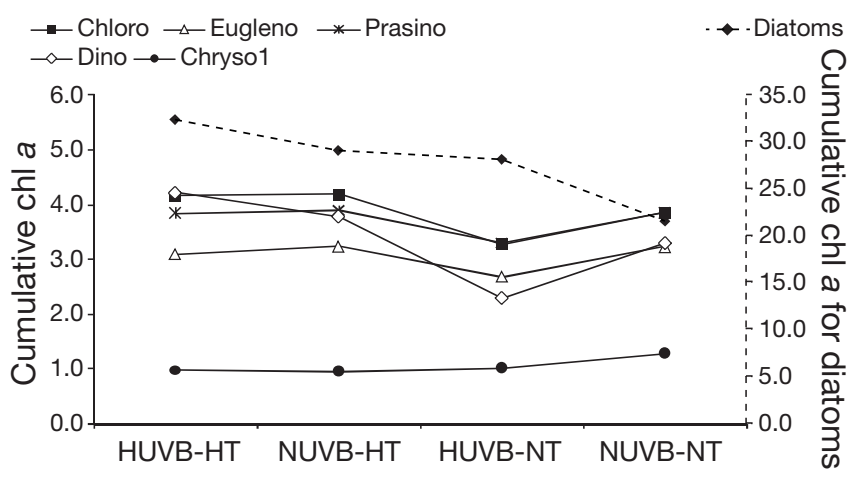

Fig. 5. Cumulative biomass (in terms of chl $a_{1} \mu \mathrm{g} \mathrm{l}^{-1}$ ) over the $8 \mathrm{~d}$ of the experiment for the major algal groups determined from CHEMTAX. See Figs. $1 \& 3$ legend for group and treatment abbreviations algal groups determined from CHEMTAX (Fig. 5), green algae (chlorophytes, prasinophytes and euglenophytes), chrysophytes and dinoflagellates showed smaller biomass accumulation in the HUVB-NT treatment compared to the other treatments (Student's $t$-test, $\mathrm{p}<0.01$ ). Diatoms, green algae and dinoflagellates withstood the enhanced UV-B conditions better under the increased temperature treatment.

\section{Photoprotective pigments}

The pool of photoprotective pigments showed much larger maximum values for the diadinoxanthinbased XC than its violaxanthinbased counterpart, consistent with the dominance of diatoms during the bloom (Fig. 6a,b). The (Viola + Zea)/ chl a ratio (antheraxanthin not detected) decreased over the first $3 \mathrm{~d}$ (with a small increase on D3), while the $(\mathrm{Dd}+\mathrm{Dt}) / \mathrm{chl}$ a ratio increased from D3 onwards, with maximum values reached during the postbloom period. No significant difference in the pool of (Dd $+\mathrm{Dt}) / \mathrm{chl} a$ was observed among treatments (RM-ANOVA, p > 0.05, Table 3a) nor their interaction. In contrast, the pool of (Viola + Zea)/chl a decreased significantly under the higher temperature treatments (Table 3a), with no significant interactions with UV-B.

The de-epoxidation state for the diadinoxanthinbased XC $\left(\mathrm{DES}_{\mathrm{Dt}}\right)$ and the violaxanthin-based $\mathrm{XC}$ $\left(D_{E S} S_{\text {Zea }}\right)$ are presented in Fig. 6c,d. Both showed maxima during the post-bloom, with no significant effect associated with the temperature or UV-B treatments or their interaction (Table 3a). Similarly, there were no significant effects when the tests were run only for the post-bloom period (Table $3 b$ ).

\section{Daily changes before and after UV-B exposure}

There was a significant difference in $F_{\mathrm{v}} / F_{\mathrm{m}}$ before and after lamp UV-B exposure (Fig. 7a,b) (Student's $t$ test, $\mathrm{p}<0.05)$, with higher $F_{\mathrm{v}} / F_{\mathrm{m}}$ values before expo- 


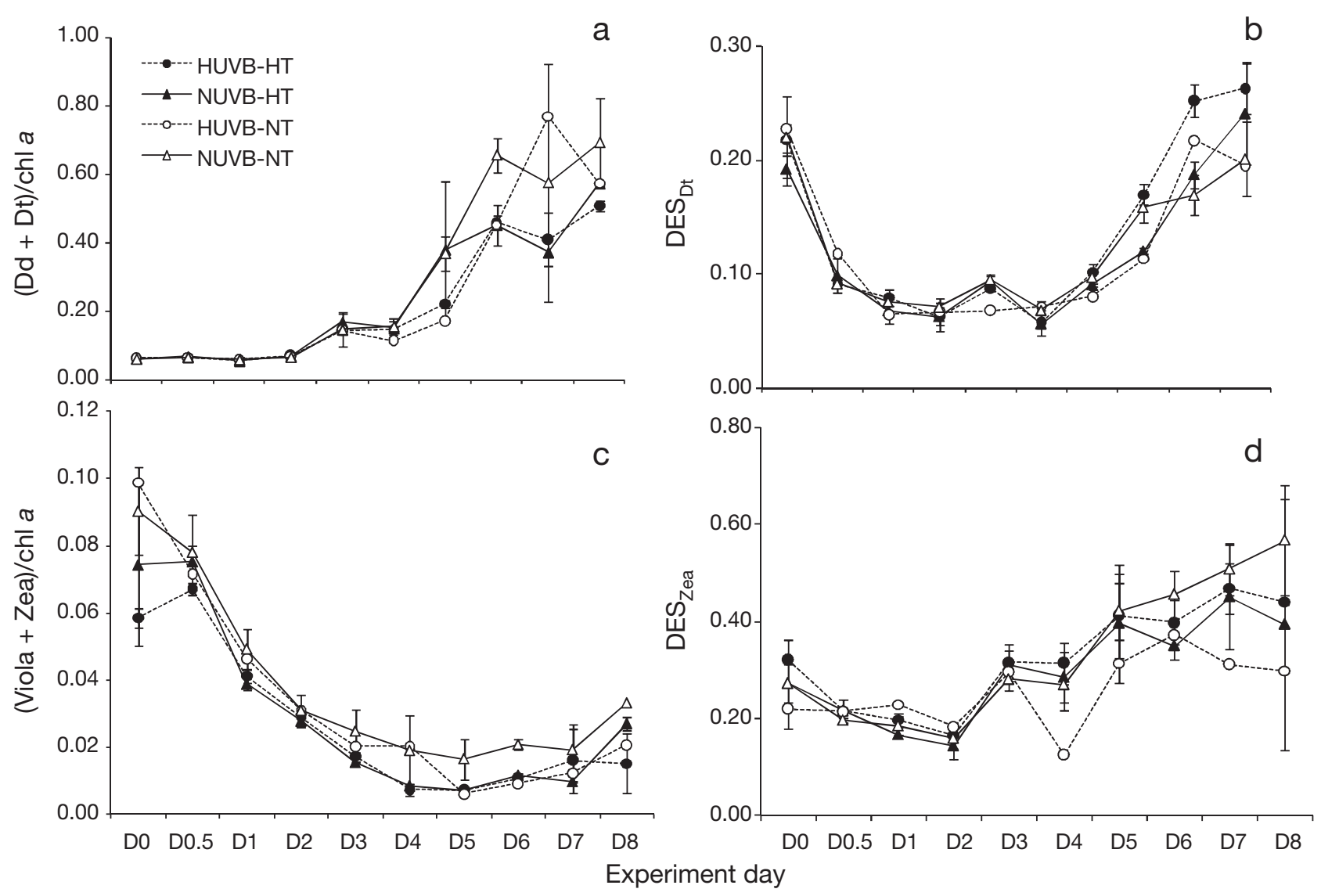

Fig. 6. Temporal patterns for the photoprotective xanthophyll cycle pigments. (a) Pool size of diadinoxanthin (Dd) and diatoxanthin (Dt) to chl a ratio. (b) Pool size of violaxanthin (Viola) and zeaxanthin (Zea) to chl a ratio. (c) De-epoxidation state for diatoxanthin $\left(\mathrm{DES}_{\mathrm{Dt}}\right)$, which is the $\mathrm{Dt} /(\mathrm{Dd}+\mathrm{Dt})$ ratio. (d) De-epoxidation state for zeaxanthin (DES $\left.\mathrm{Zea}_{\mathrm{Z}}\right)$, which is the Zea/ (Viola + Zea) ratio. See Fig. 1 legend for treatment abbreviations

sure, indicating overnight recovery. The $F_{\mathrm{v}} / F_{\mathrm{m}}$ ratio determined after daily lamp UV-B exposure generally decreased over time (Fig. $7 \mathrm{C}$ ). Hence, the quantum yield of PSII photochemistry showed progressively increasing damage with time following the daily lamp UV-B exposure, but cells recovered overnight because the morning values did not show this trend.

The pool of diadinoxanthin-based XC pigments, $(\mathrm{Dd}+\mathrm{Dt}) / \mathrm{chl} a_{1}$ also showed a significant difference before and after UV-B exposure (data not shown) with higher values after exposure (Student's $t$-test, $\mathrm{p}<0.01)$. Thus, an increase in the pool of photoprotective pigments was observed after daily lamp UV-B exposure. However, there were no significant differences among the various UV and temperature treatments.

Biomass-associated variables (chl a concentration) showed no significant differences before and after daily lamp UV-B exposure, as did the CHEMTAXderived phytoplankton composition (Student's $t$-test, $\mathrm{p}>0.05$; data not shown). The only exception was for prymnesiophytes type 3 , which were slightly higher after lamp UV-B exposure (Student's $t$-test, $p=0.024$ ), but they always represented less than $2 \%$ of the total chl a biomass of the phytoplankton community.

\section{DISCUSSION}

Results of this pigment-based study are consistent with those from a companion study in the same mesocosms, which used a pulse shape recording flow cytometer (Cytosense) to determine the fate of cell size clusters (Thyssen et al. 2011). Both investigations indicate that large cells (especially diatoms, which constituted most of the phytoplankton biomass) are favored by the increase in temperature (with or without additional UV-B), while small cells are negatively affected (Table 4a). Variable responses to temperature have been reported in previous work; while Halac et al. (2010) and Lassen et al. (2010) report a 

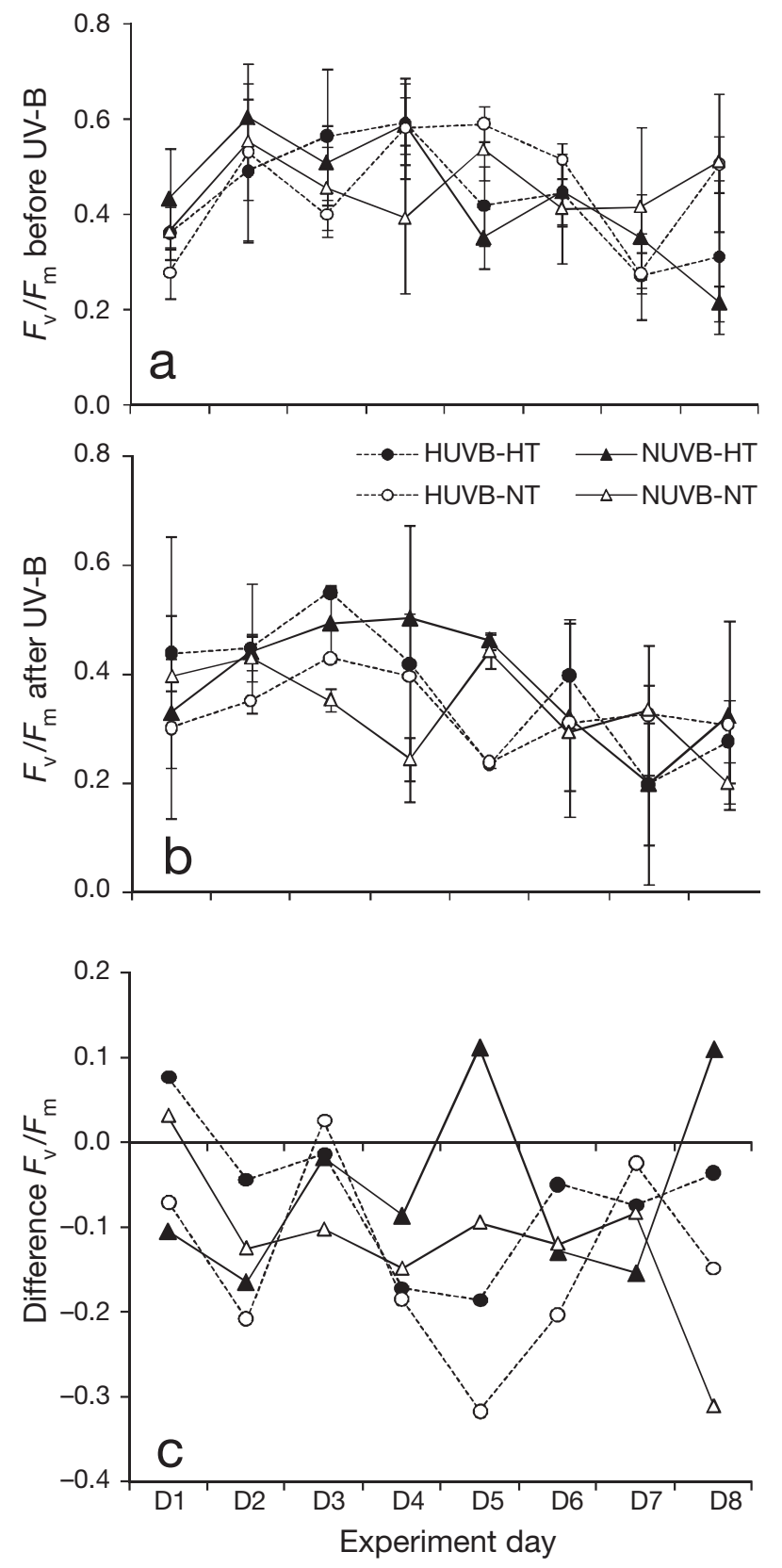

Fig. 7. Temporal patterns of the mean $( \pm \mathrm{SD})$ maximum quantum yield of the photosystem II (PSII), represented as the ratio of variable to maximum fluorescence $\left(F_{\mathrm{v}} / F_{\mathrm{m}}\right)(\mathrm{a})$ before and (b) after lamp UV-B exposure and (c) the difference in $F_{\mathrm{v}} / F_{\mathrm{m}}$ ratio between those 2 measurements (after - before) for each mesocosm treatment measured daily (Day 1, D1, to Day 8, D8). See Fig. 1 legend for treatment abbreviations

beneficial influence of a temperature increase for some diatoms, Wohlers et al. (2009) and Lewandowska \& Sommer (2010) show a negative effect of warming on large cells (particularly diatoms) possibly related to an increased respiratory demand. The characteristics of our experiment (short duration, which is appropriate for the duration of blooms in temperate environments, and mid-range temperature) are more similar to those of Lassen et al. (2010), since Wohlers et al. (2009) followed a community over $1 \mathrm{mo}$ at temperatures less than $8^{\circ} \mathrm{C}$. The variability in response to light (or UV radiation, van Donk et al. 2001) and temperature is surely affected by the composition of the phytoplankton community and probably also by acclimation processes (Villafañe et al. 1995). Our study took place during summer, at a time when cells may be expected to be well acclimated to UV radiation and warmer temperatures, which may have contributed to the observed trends. Interestingly, when using total chl a biomass (for all cells or for the small size fraction), we found no significant influence of temperature or UV-B treatments (or their interaction) over the duration of the experiment (Table 3a). Admittedly, the potential for Type II errors is greater with only 2 replicate mesocosms per treatment, but our results suggest that community information is important when examining the influence of climate-related factors such as temperature or UV radiation (as highlighted in Edwards \& Richardson 2004, Xenopoulos et al. 2009), and it also has implications for carbon transfer within the food web and export in the ocean (Ferreyra et al. 2006, Wohlers et al. 2009).

Since we only have data on phytoplankton, we do not know if indirect effects (such as reduced grazing pressure on some algal groups, Bothwell \& Sherbot 1994) contributed to the overall response. However, we can examine the available information on photosynthetic performance $\left(F_{\mathrm{v}} / F_{\mathrm{m}}\right)$ and photoprotection (XC) to see how algal physiology responded. Our working hypothesis stated that increasing temperature under conditions of enhanced UV-B would alleviate the negative effects of UV-B due to increased repair or photoprotection at higher temperature; hence these 2 factors should show a response to warming if algal physiology is important. Although these physiological variables could not be distinguished according to algal groups, results showed no significant influence of temperature or UV-B treatment on photosynthetic performance or diadinoxanthin-based xanthophyll cycle pool size (likely associated with diatoms, the dominant algal group, Table 3a), suggesting either that there were compensation effects among various algal groups or that trophic-related indirect effects contributed more importantly to the overall response than algal physiology. However, this may not be the case for small cells, since the decrease of small cells under warming was accompanied by a smaller pool size of viola- 
xanthin-based XC (likely associated with green algal groups). Hence physiological adjustments may have contributed to the response of small cells.

Several authors have highlighted the interactive effects of temperature and nutrient limitation on the response of phytoplankton to UV radiation (e.g. Doyle et al. 2005 and a review on interactions between UV and nutrient limitation by Beardall et al. 2009). Although in some cases, nutrient depleted cells have shown no response to UV (as in Doyle et al. 2005), previous studies from our group have shown that cells already stressed by nutrient depletion exhibit a more negative response to UV-B (Longhi et al. 2006, Bouchard et al. 2008). In any case, there is a need to consider the influence of nutrients on the temperature and UV-B response, even in large-sized estuaries where nutrients can be occasionally depleted during summer. In the present study, although nutrients were not included as a treatment factor, we compared responses obtained over the whole duration of the experiment with those from the nutrient-limited post-bloom period. The UV-B treatment showed a significant influence only during post-bloom, but contrary to expectation, there was an increase under the enhanced UV-B treatments (Table 3b), particularly for small cells (Table $4 \mathrm{~b}$ ). However, this trend was significant only at normal temperature (significant UV $\times$ temperature interaction for small cells, Table $4 \mathrm{~b}$ ), while the influence of UV-B disappeared under warmer conditions. These results contrast with the expected negative influence of enhanced UV-B. Instead, they show a greater biomass accumulation with enhanced UV-B (only at normal temperature for small cells) during the post-bloom period, consistent with the increase in cell abundance of several flow cytometer clusters observed by Thyssen et al. (2011), which they interpret to be due to faster cell cycles. Phytoplankton composition changed after the diatom bloom, with new algal groups (e.g. prymnesiophytes, Fig. 4) seemingly well adapted to the UV conditions of this experiment.

Whether we consider all $8 \mathrm{~d}$ of the experiment or only the post-bloom period, our data do not support the hypothesis that increasing the temperature will reduce negative UV-B effects. Significant interaction between these 2 factors is seen only during the nutrient-limited post-bloom period and mostly for small cells, and enhancing UV-B had positive effects instead of negative ones. Our results suggest that under a warming scenario with no changes in UV-B levels, large cells (mostly diatoms) would be favored over small cells, while under an enhanced UV-B sce- nario with no change in temperature, there would be little change in phytoplankton biomass (total and community-wise), except under conditions of nutrient limitation where small cells would be favored under enhanced UV-B. Under a scenario where both temperature and UV-B would increase, as predicted from climate change models, our results suggest that diatoms would be most favored in terms of cumulative biomass over the duration of an average bloom in temperate environments (of the order of 1 to $2 \mathrm{wk}$, Fig. 5) and they indicate no significant interaction between these 2 factors, except under nutrient-limited conditions where the influence of UV-B on small cells would be reduced with warming.

According to some authors (Hashioka \& Yamanaka 2007, Daufresne et al. 2009), one of the consequences of global warming is a shift to smaller-sized species. Our results do not concur with this, since small cells showed a decrease with increased temperature while large cells increased (Table 4a), potentially favoring the herbivorous food web (Thyssen et al. 2011). A lot of variability can be expected in these responses, depending on the particular assemblages of algal prey and predators and their sensitivity to temperature or other factors. Furthermore, shifts in cell size in a plankton community can be the result of changes in grazing pressure (Lewandowska \& Sommer 2010) that were not examined here but are also difficult to generalize since UV sensitivity of ciliates and other grazers is quite variable (Sommaruga 2003).

Although extrapolation to natural systems is limited since mesocosm experiments such as this one do not include larger size grazers and do not consider the indirect effects of temperature such as changes in the depth of the surface mixed layer and reduced nutrient supply, our results highlight a greater influence of temperature than of UV-B. This concurs with recent studies that have looked at interactions between temperature and light or UV radiation, such as Lewandowska \& Sommer (2010) and Vidussi et al. (2011). In lakes, Xenopoulos et al. (2009) proposed that nutrient limitation and temperature play a greater role than UV radiation in structuring phytoplankton communities. Aside from metabolic stimulation and its effect on stratification, temperature may have another indirect effect on these communities, through its influence on various zooplankton groups, driving a number of trophic cascade effects (Vidussi et al. 2011).

In summary, this study examined the influence of increased temperature and UV-B radiation on a coastal planktonic ecosystem enclosed in mesocosms for $8 \mathrm{~d}$. The response of algal groups was followed 
using pigment markers. Overall, only temperature was significant, with inverse effects between small cells (decreasing with temperature) and larger cells (increasing with temperature). Our results suggest that diatoms would benefit the most under a scenario of warming and enhanced UV-B levels. Although consistent with several recent studies that point out the prominent role of temperature, our results differ with some of them, in that warming benefited large phytoplankton and negatively affected small cells. A greater understanding of these responses would benefit from knowledge of trophic cascade effects, but this was outside the scope of the present study. Variability in the results obtained from different studies highlights the need for more research on the interactions between temperature, nutrient limitation and UV radiation, and possibly also other climate change related factors such as acidification.

Acknowledgements. This research is part of a project entitled 'Combined effects of ultraviolet-B radiation, increased $\mathrm{CO}_{2}$ and climate warming on the biological pump: a temporal and latitudinal study', granted to S. Demers by the Natural Sciences and Engineering Research Council of Canada (NSERC, SRO Grant\# 334876-2005). M.L. was supported by the Postdoctoral Merit Scholarship Program for Foreign students from the Fonds Québécois de Recherche sur la Nature et les Technologies (FQRNT). D. Lavallée, P. Rioux and E. Pelletier are thanked for providing nutrients data. Special thanks to S. Leblanc, B. Cayouette and P. Poulin for assistance with setting up and running the mesocosms experiment. We are grateful to anonymous referees whose comments greatly improved an earlier version of this paper.

\section{LITERATURE CITED}

Armstrong FAJ, Stearns CR, Strickland JDH (1967) The measurement of upwelling and subsequent biological process by means of the Technicon Autoanalyzer and associated equipment. Deep-Sea Res 14:381-389

> Beardall J, Sobrino C, Stojkovic S (2009) Interactions between the impacts of ultraviolet radiation, elevated $\mathrm{CO}_{2}$, and nutrient limitation on marine primary producers. Photochem Photobiol Sci 8:1257-1265

Bothwell ML, Sherbot DMJ, Pollock CM (1994) Ecosystem response to solar ultraviolet-B radiation: influence of trophic-level interactions. Science 265:97-100

Bouchard JN, Roy S, Campbell DA (2006) UVB effects on the photosystem II-D1 protein of phytoplankton and natural phytoplankton communities. Photochem Photobiol 82: 936-951

Bouchard JN, Longhi ML, Roy S, Campbell DA, Ferreyra G (2008) Interaction of nitrogen status and UVB sensitivity in a temperate phytoplankton assemblage. J Exp Mar Biol Ecol 359:67-76

- Brunet C, Brylinski JM, Lemoine Y (1993) In-situ variations of the xanthophylls diatoxanthin and diadinoxanthin: photoadaptation and relationships with a hydrodynamical system in the eastern English Channel. Mar Ecol Prog Ser 102:69-77
Buma AGJ, van Oijen T, van de Poll W, Veldhuis MJW, Gieskes WWC (2000) The sensitivity of Emiliania huxleyi (Prymnesiophyceae) to ultraviolet-B radiation. J Phycol 36:296-303

Butler WL (1978) Energy distribution in the photochemical apparatus of photosynthesis. Annu Rev Plant Physiol 29: 345-378

Chatila K, Demers S, Mostajir B, Gosselin M, Chanut JP, Monfort P, Bird D (2001) The responses of a natural bacterioplankton community to different levels of ultravioletB radiation: a food web perspective. Microb Ecol 41: 56-68

Comiso JC, Parkinson CL, Gersten R, Stock L (2008) Accelerated decline in the Arctic sea ice cover. Geophys Res Lett 35:L01703, doi:10.1029/2007GL031972

Dameris M (2010) Depletion of the ozone layer in the 21st century. Angew Chem Int Ed Engl 49:489-491

Daufresne M, Lengfellner K, Sommer U (2009) Global warming benefits the small in aquatic ecosystems. Proc Natl Acad Sci USA 106:12788-12793

Davison IR (1991) Environmental effects on algal photosynthesis: temperature. J Phycol 27:2-8

> Demmig-Adams B, Adams WW (1996) The role of xanthophyll cycle carotenoids in the protection of photosynthesis. Trends Plant Sci 1:21-26

Díaz SB, Camilión C, Lacoste K, Escobar J, Demers S, Gianesella S, Roy S (2003) Simulation of increasing UV radiation as a consequence of ozone depletion. In: Slusser JR, Herman JR, Gao W (eds) Ultraviolet ground- and spacebased measurements, models and effects III. Proc 48th SPIE 5156. SPIE, Belham, WA, p 216-227

Díaz S, Camilión C, Escobar J, Deferrari G and others (2006) Simulation of ozone depletion using ambient irradiance supplemented with UV lamps. Photochem Photobiol 82: 857-864

> Doyle SA, Saros JE, Williamson CE (2005) Interactive effects of temperature and nutrient limitation on the response of alpine phytoplankton growth to ultraviolet radiation. Limnol Oceanogr 50:1362-1367

> Edwards M, Richardson AJ (2004) Impact of climate change on marine pelagic phenology and trophic mismatch. Nature 430:881-884

Ferreyra GA, Mostajir B, Schloss IR, Chatila K and others (2006) Ultraviolet-B radiation effects on the structure and function of lower trophic levels of the marine planktonic food web. Photochem Photobiol 82:887-897

Grasshoff K, Ehrhardt M, Kremling K (1983) Methods of seawater analysis, 2nd edn. Verlag Chemie, Weinheim

Häder DP (2011) Does enhanced solar UV-B radiation affect marine primary producers in their natural habitats? Photochem Photobiol 87:263-266

> Halac SR, Villafañe VE, Helbling EW (2010) Temperature benefits the photosynthetic performance of the diatoms Chaetoceros gracilis and Thalassiosira weissflogii when exposed to UVR. J Photochem Photobiol B 101:196-205

> Hashioka T, Yamanaka Y (2007) Ecosystem change in the western North Pacific associated with global warming using 3D-NEMURO. Ecol Model 202:95-104

- Hoffman JR, Hansen LJ, Klinger T (2003) Interactions between UV radiation and temperature limit inferences from single-factor experiments. J Phycol 39:268-272

Hooker SB (2005) The second SeaWiFS HPLC analysis round-robin experiment (SeaHARRE-2). NASA/TM2005-212785, Greenbelt, MD

IPCC (Intergovernmental Panel on Climate Change) (2007) 
Climate change 2007: synthesis report. Contribution of working groups I, II and III to the fourth assessment report of the Intergovernmental Panel on Climate Change. IPCC, Geneva

Jeffrey SW, Wright SW (2006) Photosynthetic pigments in marine microalgae: insights from cultures and the sea. In: Subba Rao DV (ed) Algal cultures, analogues of blooms and applications, Vol 1. Science Publishers, Enfield, $\mathrm{NH}_{\text {, }}$ p 33-90

Kemp WM, Petersen JE, Gardner RH (2001) Scale-dependence and the problem of extrapolation: implications for experimental and natural coastal ecosystems. In: Gardner RH, Kemp WM, Kennedy VS, Petersen JE (eds) Scaling relations in experimental ecology. Columbia University Press, New York, NY, p 3-57

Kerr JB, McElroy CT (1993) Evidence for large upward trends of ultraviolet-B radiation linked to ozone depletion. Science 262:1032-1034

Korbee N, Mata MT, Figueroa FL (2010) Photoprotection mechanisms against ultraviolet radiation in Heterocapsa sp. (Dinophyceae) are influenced by nitrogen availability: mycosporine-like amino acids vs. xanthophyll cycle. Limnol Oceanogr 55:899-908

Lassen MK, Nielsen KD, Richardson K, Garde K, Schlüter L (2010) The effects of temperature increases on a temperate phytoplankton community-a mesocosm climate change scenario. J Exp Mar Biol Ecol 383:79-88

> Lewandowska A, Sommer U (2010) Climate change and the spring bloom: a mesocosm study on the influence of light and temperature on phytoplankton and mesozooplankton. Mar Ecol Prog Ser 405:101-111

- Longhi ML, Ferreyra G, Schloss I, Roy S (2006) Variable phytoplankton response to enhanced UV-B and nitrate addition in mesocosm experiments at three latitudes (Canada, Brazil and Argentina). Mar Ecol Prog Ser 313: $57-72$

> MacIntyre HL, Cullen JJ (1996) Primary production by suspended and benthic microalgae in a turbid estuary: timescales of variability in San Antonio Bay, Texas. Mar Ecol Prog Ser 145:245-268

> Mackey MD, Mackey DJ, Higgins HW, Wright SW (1996) CHEMTAX - a program for estimating class abundances from chemical markers: application to HPLC measurements of phytoplankton. Mar Ecol Prog Ser 144:265-283

Madronich S, McKenzie RL, Caldwell MM, Björn LO (1995) Changes in ultraviolet radiation reaching the Earth's surface. Ambio 24:143-152

Malkin S, Kok B (1966) Fluorescence induction studies in isolated chloroplast. I. Number of components involved in the reaction and quantum yields. Biochim Biophys Acta 126:413-432

McKenzie RL, Aucamp PJ, Bais AF, Björn LO, Ilyas M (2007) Changes in biologically-active ultraviolet radiation reaching the Earth's surface. Photochem Photobiol Sci 6: 218-231

Moline MA (1998) Photoadaptive response during the development of a coastal Antarctic diatom bloom and relationship to water column stability. Limnol Oceanogr 43: 146-153

> Mostajir B, Demers S, de Mora S, Belzile C and others (1999) Experimental test of the effect of ultraviolet-B radiation in a planktonic community. Limnol Oceanogr 44:586-596

> Mousseau L, Gosselin M, Levasseur M, Demers S and others (2000) Effects of ultraviolet B radiation on simultaneous carbon and nitrogen transport rates by estuarine phyto- plankton during a week-long mesocosm study. Mar Ecol Prog Ser 199:69-81

Murphy J, Riley JP (1962) A modified single solution method for the determination of phosphate in natural waters. Anal Chim Acta 27:31-36

Neale PJ, Kieber DJ (2000) Assessing biological and chemical effects of UV in the marine environment: spectral weighting functions. In: Hester RE, Harrison RM (eds) Causes and environmental implications of increased UV$\mathrm{B}$ radiation. Issues in Environmental Science and Technology, Vol 14. The Royal Society of Chemistry, Cambridge, p 61-83

Neale PJ, Helbling EW, Zagarese HE (2003) Modulation of UVR exposure and effects by vertical mixing and advection. In: Helbling EW, Zagarese H (eds) UV effects in aquatic organisms and ecosystems, Vol 1. The Royal Society of Chemistry, Cambridge, p 107-134

> Olaizola M, Laroche J, Kolber Z, Falkowski PG (1994) Nonphotochemical fluorescence quenching and the diadinoxanthin cycle in a marine diatom. Photosynth Res 41: $357-370$

> Petersen JE, Kemp WM, Bartleson R, Boynton WR and others (2003) Multiscale experiments in coastal ecology: improving realism and advancing theory. Bioscience 53: 1181-1197

Rautenberger R, Bischof K (2006) Impact of temperature on UV-susceptibility of two Ulva (Chlorophyta) species from Antarctic and Subantarctic regions. Polar Biol 29: 988-996

Roleda MY (2009) Photosynthetic response of Arctic kelp zoospores exposed to radiation and thermal stress. Photochem Photobiol Sci 8:1302-1312

- Roos JC, Vincent WF (1998) Temperature dependence of UV radiation effects on Antarctic cyanobacteria. J Phycol 34: 118-125

> Roy S, Chanut JP, Gosselin M, Sime-Ngando T (1996) Characterization of phytoplankton communities in the lower St. Lawrence Estuary using HPLC-detected pigments and cell microscopy. Mar Ecol Prog Ser 142:55-73

> Roy S, Mohovic B, Gianesella SMF, Schloss I, Ferrario M, Demers S (2006) Effects of enhanced UV-B on pigmentbased phytoplankton biomass and composition of mesocosm-enclosed natural marine communities from three latitudes. Photochem Photobiol 82:909-922

> Ruban AV, Lavaud J, Rousseau B, Guglielmi G, Horton P, Etienne AL (2004) The super-excess energy dissipation in diatom algae: comparative analysis with higher plants. Photosynth Res 82:165-175

Shepherd A, Wingham D (2007) Recent sea-level contributions of the Antarctic and Greenland ice sheets. Science 315:1529-1532

Sobrino C, Neale PJ, Montero O, Lubián LM (2005) Biological weighting function for xanthophyll de-epoxidation induced by ultraviolet radiation. Physiol Plant 125: $41-51$

Sommaruga R (2003) UVR and its effects on species interactions. In: Helbling W, Zagarese $\mathrm{H}$ (eds) UV effects in aquatic organisms and ecosystems, Vol 1. Comprehensive Series in Photochemistry \& Photobiology. The Royal Society of Chemistry, Cambridge p 485-508

Steeneken SF, Buma AGJ, Gieskes WWC (1995) Changes in transmission characteristics of polymethylmethacrylate and cellulose (III) acetate during exposure to ultraviolet light. Photochem Photobiol 61:276-280

Stenger R (2002) Antarctic ozone hole splits in two. Available 
at www.cnn.com/2002/TECH/space/09/30/ozone.holes/

Talling JF (1971) The underwater light climate as a controlling factor in the production ecology of freshwater phytoplankton. Mitt Int Ver Theor Angew Limnol 19:214-243

Thyssen M, Ferreyra G, Moreau S, Schloss S, Denis M, Demers S (2011) The combined effect of ultraviolet B radiation and temperature increase on phytoplankton dynamics and cell cycle using pulse shape recording flow cytometry. J Exp Mar Biol Ecol 406:95-107

van de Poll WH, Buma AGJ (2009) Does ultraviolet radiation affect the xanthophyll cycle in marine phytoplankton? Photochem Photobiol Sci 8:1295-1301

van de Poll WH, Eggert A, Buma AGJ, Breeman AM (2002) Temperature dependence of UV radiation effects in Arctic and temperature isolates of three red macrophytes. Eur J Phycol 37:59-68

van Donk E, Faafeng BA, de Lange HJ, Hessen DO (2001) Differential sensitivity to natural ultraviolet radiation among phytoplankton species in Arctic lakes (Spitsbergen, Norway). Plant Ecol 154:247-259

Velicogna I (2009) Increasing rates of ice mass loss from the Greenland and Antarctic ice sheets revealed by GRACE. Geophys Res Lett 36:L19503, doi:10.1029/2009GL04022

Vidussi F, Mostajir B, Fouilland E, Le Floc'h E and others (2011) Effects of experimental warming and increased

Editorial responsibility: Katherine Richardson, Copenhagen, Denmark ultraviolet $\mathrm{B}$ radiation on the Mediterranean plankton food web. Limnol Oceanogr 56:206-218

> Villafañe VE, Helbling EW, Holm-Hansen O, Chalker BE (1995) Acclimatization of Antarctic natural phytoplankton assemblages when exposed to solar ultraviolet radiation. J Plankton Res 17:2295-2306

- Vincent WF, Roy S (1993) Solar ultraviolet-B radiation and aquatic primary production: damage, protection and recovery. Environ Rev 1:1-12

WMO (World Meteorological Organization) (2003) Scientific assessment of ozone depletion: 2002, global ozone research and monitoring project, Report No. 47. WMO, Geneva

Wohlers J, Engel A, Zöllner E, Breithaupt P and others (2009) Changes in biogenic carbon flow in response to sea surface warming. Proc Natl Acad Sci USA 106: 7067-7072

Xenopoulos MA, Leavitt PR, Schindler DW (2009) Ecosystem-level regulation of boreal lake phytoplankton by ultraviolet radiation. Can J Fish Aquat Sci 66:2002-2010

Zapata M, Rodríguez F, Garrido JL (2000) Separation of chlorophylls and carotenoids from marine phytoplankton: a new HPLC method using a reversed phase $\mathrm{C}_{8}$ column and pyridine-containing mobile phases. Mar Ecol Prog Ser 195:29-45

Submitted: January 12, 2011; Accepted: November 5, 2011 Proofs received from author(s): January 11, 2012 